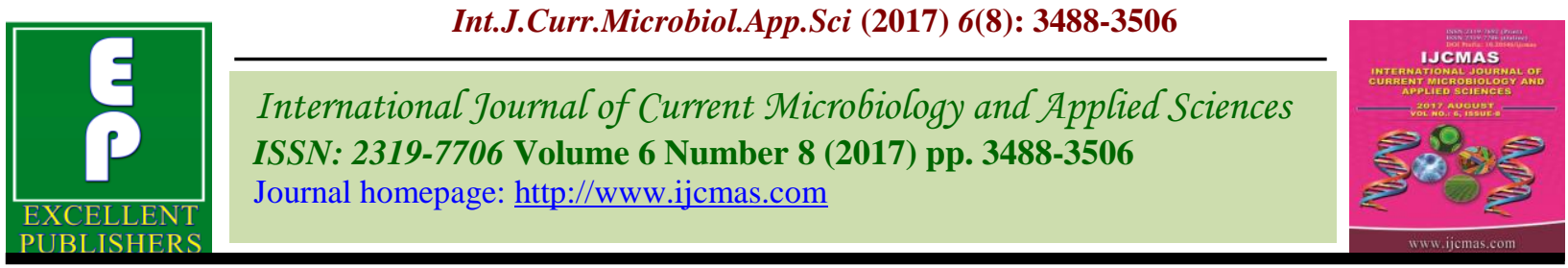

Review Article

https://doi.org/10.20546/ijcmas.2017.608.418

\title{
Key Agronomic Issues for Higher Production and Sustainability in Bt Cotton: A Review
}

\author{
Vinayak Hosamani*, B.M. Chittapur and Venkatesh D. Hosamani
}

Department of Agronomy, University of Agricultural Science, Raichur-584102, Karnataka, India Department of Entomology, College of Horticulture, Munirabad, Koppal-583234, India

*Corresponding author

\section{A B S T R A C T}

\section{Keywords \\ Bt cultivars, Time of sowing, \\ Transplanting, \\ Nutrition, Target yield approach. \\ Article Info \\ Accepted: \\ 27 June 2017 \\ Available Online: \\ 10 August 2017}

With the advent of $B t$ cultivars cotton production is reinvigorated in the country with China being on the verge of being knocked down on the production front. However, of late the stagnating or the decreasing productivity either due to degrading natural resources and faulty practices and/or susceptibility of transgenic cultivars to insect damage, leaf reddening and climate change are making the researcher to take stock of the situation before embarking on agronomic studies with higher yield goals. Hence, the review.

\section{Introduction}

The development of $B t$ cotton represents a significant technological evolution in the global cotton research. India adopted this technology during 2002. Commercial cultivation of $B t$ cotton in India began during 2002-03 with three hybrids viz., MECH-12 $B t$, MECH-162 Bt and MECH-184 Bt (Anon., 2006) and during 2008 there were 274 hybrids officially approved by the Genetic Engineered Approval Committee (GEAC) and today the number is unimaginable. Today $B t$ cultivars cover almost entire cotton zones of India, the productivity has more than trebled over the initial level at the time of $B t$ introduction. However, of late the production is either stagnant or showing downward trend and therefore, it is imperative to take stock of key agronomic issues for integrated acceleration of cotton production across climate change particularly drought, changing pest scenario, leaf reddening etc. This is the key for furtherance of realization of crop potential and hence, this attempt.

\section{Selection of cultivars}

In India several studies have been carried out on the field performance of $B t$ hybrids since their release (Table 1). Initial multi-location trials conducted under the aegis of Indian Council of Agricultural Research for three hybrids (viz. MECH-12, MECH-162 and $\mathrm{MECH}-184$ ) indicated increase in yield over the local popular non- $B t$ cotton, and among the $B t$ cotton hybrids, MECH 162 recorded significantly higher seed cotton yield (Anon., 2002). Venugopalan et al., (2002) revealed that MECH-162 Bt fared better in central zone 
(13.3 $\mathrm{q} \mathrm{ha}^{-1}$ ) while MECH-184 Bt did well in south zone $\left(20.09 \mathrm{q} \mathrm{ha}^{-1}\right)$. Similarly, in Karnataka, Khadi et al., (2002) revealed the superiority of MECH-184 Bt. In further south, on clay loam soil at Coimbatore MECH-162 recorded higher seed cotton yield, number of sympodials and number of bolls over non- $B t$ hybrids (Sankaranarayanan, 2004).

Under unprotected rainfed condition at Dharwad, Udikeri et al., (2003a) recorded significantly lower damage to fruiting bodies in MECH-184 Bt (4.04\%) followed by MECH-162 Bt (5.02\%) and MECH-12 Bt (6.84\%). Kengegowda (2003) also observed significantly higher good opened bolls and less bad opened bolls in $B t$ cotton hybrids in Raichur. Vennila et al., (2004) revealed significantly lower square, green boll, open boll and locule damage in RCH-20, RCH134, RCH-138 and RCH-144 Bt. Similarly, Bhosle et al., (2004) reported significantly lower damage due to bollworms (14 to $17 \%$ ) in $B t$ cotton hybrids compared to non- $B t$ and check hybrids (25 to 35\%). Surulivelu et al., (2004) reported that RCH-2 Bt and RCH - 20 $B t$ were effective in reducing the $H$. armigera incidence to the extent of 73.8 and $72.9 \%$ over their non- $B t$ counterparts. Interestingly, Jagvirsingh et al., (2003) noticed earliness nearly by 40 days in $B t$ hybrids. Mayee et al., (2004) also had similar observation.

In the north eastern dry zone, at Research Farm, Raichur and on farmer's field incidence of bollworms in MECH-162 Bt and MECH$184 B t$ cotton hybrids was negligible (Patil et al., 2004). At Dharwad, Halemani et al., (2004) found higher yield with RCH-2 Bt $\left(2857 \mathrm{~kg} \mathrm{ha}^{-1}\right)$ followed by RCH-144 Bt (2794 $\left.\mathrm{kg} \mathrm{ha}{ }^{-1}\right)$, RCH-20 Bt (2585 $\left.\mathrm{kg} \mathrm{ha}^{-1}\right)$ and MECH-184 Bt $\left(2575 \mathrm{~kg} \mathrm{ha}^{-1}\right)$ while at College Farm, Dharwad, RCH-20 performed better (Yenagi, 2006). In Guntur district of Andhra Pradesh, Chandrasekhar Reddy et al., (2005) observed higher overall average yield with
MECH-12 Bt and MECH-184 Bt (1231 kg acre $^{-1}$ ) over commercial checks (1149 kg acre $\left.{ }^{1}\right)$ while Prasad and Rao (2008) reported superiority of RCH $20 \mathrm{Bt}$ in terms of higher $(2.5 \%)$ staple length $(30.61 \mathrm{~mm}), 5 \%$ staple length $(15.03 \mathrm{~mm})$ and elongation $(6.33 \%)$, however, $B t$ hybrids were comparable with respect to uniformity ratio, micronaire and fibre strength.

Similarly, JK-CH $99 B t$ was outstanding $\left(3323 \mathrm{~kg} \mathrm{ha}^{-1}\right)$ while JK- Durga Bt $(3302 \mathrm{~kg}$ $\left.\mathrm{ha}^{-1}\right)$, MRC-6322 Bt (3230 kg ha $\left.{ }^{-1}\right)$ and NCS207 Bt (2927 kg ha ${ }^{-1}$ ) were on par (Joshi, 2007). Bunny $B t$ was also found competitive (2672 $\mathrm{kg} \mathrm{ha}^{-1}$ ) with $30.96 \%$ higher seed cotton yield, 39\% more number of bolls plant ${ }^{-}$ ${ }^{1}$ and $9.02 \%$ more boll weight than the non- $B t$ cotton hybrids (Rekha, 2007). This was attributed to its close association with number of bolls per plant $(\mathrm{r}=0.53)$. RCH-144 $B t$ had good micronaire value (3.9) and elongation (5.2) with higher (2.5\%) SL (30.0) and high tenacity $\left(22.8 \mathrm{~g} \mathrm{tex}^{-1}\right)$ (Khadi et al., 2008), while RCH $20 B t$ had more UR (51\%) and maturity ratio (0.77). At Raichur, significantly higher uniformity ratio (47.83) and bundle strength (24.43 $\mathrm{g}^{-1}$ tex ${ }^{-1}$ were observed with MCCH- 184 Bt (Anand et al., 2009). However, significantly higher elongation percentage was noticed with Bunny (6.7) followed by RCH-2 Bt (6.1) and MECH-184 Bt (5.9).

In south-western districts of Punjab, MRC6029 Bt (Pankaj et al., 2009) and at Faridkot, RCH 314 Bt (2749 kg ha-1), NCS 138 Bt (2311 kg ha $\left.{ }^{-1}\right)$, NECK 6R Bt (2268 kg ha $\left.{ }^{-1}\right)$ and JKCH 1947 Bt $\left(2200 \mathrm{~kg} \mathrm{ha}^{-1}\right)$ fared better. At Nagpur, Maharashtra, the highest fibre bundle strength $\left(25.0 \mathrm{~g} \mathrm{tex}^{-1}\right)$ was recorded by $\mathrm{RCH} 386 \mathrm{Bt}$ hybrid and it had micronaire of 3.0 (Palve et al., 2009). Phad et al., (2009a) at Nanded revealed superior performances of MRC 7301 BG II, NCS 954 BG II, NCS 207 BG II, NSPL 999 BG I and NCS 145 BG I for 
fibre characters. Further, Ankur-651 BG-I and NHH-44 (non-Bt), and MRC-7301 BG-II Bt hybrids recorded superior staple length of $29.4 \mathrm{~mm}$ while, Ajeet-II BG-II recorded higher ginning percentage (37.0) over check and RCH-2 BG-I (36.66\%) (Phad et al., 2009b). While at Parbhani, Atal BG II, Ankur Akka BG II, Ankur Jai BG I, Dhruv Bt and Sigma $B t$ performed well (Chinchane et al., 2009). Gitte et al., (2009) observed higher seed cotton yield (1358 kg ha ${ }^{-1}$ ) with Bunny Bt.

Gopalakrishnan et al., (2009) observed better performance of Bunny and Mallika. The activity of the enzyme increased significantly from 2.11- $2.92 \mu \mathrm{mol} \mathrm{NO} \mathrm{Ng}^{-1}$ fresh weight on $30^{\text {th }}$ day after sowing to $3.31-3.93 \mu \mathrm{mol}$ $\mathrm{NO}_{2} \mathrm{~g}^{-1}$ fresh weight on $60^{\text {th }}$ day after sowing irrespective of the atmosphere in which the hybrids were grown. While, Poongothai et al., (2010) at Chennai reported significantly higher chlorophyll content with MECH- 184 over RCH 2 Bt cotton.

At Dharwad, Karnataka, Pawar et al., (2009) reported significantly higher photosynthesis, relative water content, NRA and chlorophyll content with NHH-44 Bt while, Patil et al., (2011) reported significantly higher photosynthesis, chlorophyll content, transpiration, conductance and SPAD value with MRC-6322 compared to $\mathrm{RCH} 2 B t$. Sharma et al., (2009) reported good fibre properties of $26.8 \mathrm{~mm}$ fibre length, 4.0 micronaire and strength of $21.8 \mathrm{~g} \mathrm{tex}^{-1}$ with IT-905.

$B t$ cotton hybrids also depicted wide range ginning out turn for intra-hirsutum hybrids ranging from 28.17 to $39.22 \%$ and $2.5 \%$ while span length ranged from medium (23.59 $\mathrm{mm})$ to long $(34.72 \mathrm{~mm})$ and micronaire value between fine (2.9) to medium (4.78) (Sarang et al., 2010). At Raichur, Bunny Bt BG-II had significantly higher ginning out turn $(37.39 \%)$, mean fibre length $(31.73 \mathrm{~mm})$, uniformity ratio $(48.67 \%)$ and bundle strength (24.08 $\mathrm{g} \mathrm{tex}^{-1}$ ) (Manjunatha et al., 2010b). However, maturity ratio and micronaire value did not differ significantly among the genotypes. At Nanded, MRC 7301 BG II $\left(2095 \mathrm{~kg} \mathrm{ha}^{-1}\right)$ and Ajeet 11 13G 11(1928 kg $\mathrm{ha}^{-1}$ ) were significantly superior to checks, Ankur 651 BG I and NHH 44 Non-Bt (Phad et al., 2010).

At Coimbatore, Tamil Nadu, Rajarathinam et $a l$. , (2011) reported that Lakshmi Bt recorded $34.34 \mathrm{~mm}$ of fibre length while, Tulasi 162 , SP 7149, Tulasi 171 and VBCH 1543 recorded fibre length of more than $24 \mathrm{~g} \mathrm{tex}^{-1}$. At Dharwad, JK Durga (BG I) Bt recorded significantly higher fibre fineness (3.96 micronaire) (Hosmath, 2011). While, Neeraja $B t$ recorded higher bundle strength $(25.60 \mathrm{~g}$ tex $^{-1}$ ) while JK Durga (BG 1) Bt (25.52 $\mathrm{g}^{\text {tex }}$ $\left.{ }^{1}\right)$, DCH-32 non-Bt hybrid (25.42 $\mathrm{g} \mathrm{tex}^{-1}$ ) and JK Durga non $B t\left(25.12 \mathrm{~g} \mathrm{tex}^{-1}\right)$ were on par. On farmers' field at Belgaum, Karnataka Sudha (2011) obtained significantly higher seed cotton yield (2385 $\mathrm{kg} \mathrm{ha}^{-1}$ ) with Bunny BG-II. She also observed significantly higher 2.5 per cent span length in $\mathrm{RCH}-708 \mathrm{Bt}$ while, higher fibre fineness and fibre maturity were observed in JK-99 Bt. Genotypes, however, did not differ significantly with respect to bundle strength.

At Nagpur, CNHH $2 B t$ recorded significantly high ginning out turn (GOT) (42\%) while CNHH 13 Bt recorded highest 2.5\% span length $(27.3 \mathrm{~mm})$ (Singh et al., 2011). The fibre strength was the highest for CNHH 12 (20 $\mathrm{g} \mathrm{tex}^{-1}$ ) compared to other $B t$ cotton hybrids. Manjunatha et al., (2010a) at Raichur, reported significantly higher seed cotton yield (2155 kg ha ${ }^{-1}$ ) while in Upper Krishna Project at Bheemarayanagudi with $\mathrm{KCH}-135 \mathrm{Bt}$, Akka Bt and RCH-530 Bt (1938, 1859 and $1613 \mathrm{~kg} \mathrm{ha}^{-1}$, respectively) performed better (Venkateshalu, et al., 2010). 
At Ludhiana, RCH 134 was superior (Sukhbir singh, 2010), while at New Delhi on sandy loam soil, MRC-6304 (5.30 t ha ${ }^{-1}$ ) (Ahlawat and Gangaiah (2010) and MRC-7017 Bt $(2.7 \mathrm{t}$ ha $^{-1}$ ) (Gujar et al., 2011) were outstanding. At Coimbatore, SP7157 BG II (3104 kg ha ${ }^{-1}$ ) and SP7149 BG II (2601 kg ha ${ }^{-1}$ ) were promising. Further, Rajendran et al., (2011) from same place reported highest seed cotton yield with MECH-162 (2459 kg ha ${ }^{-1}$ ). At Banswara and Udaipur (Rajasthan), JCH 50005 Bt recorded higher yield (1952 $\mathrm{kg} \mathrm{ha}^{-1}$ ) (Saini et al., 2011). At Faridkot, Kulvir Singh et al., (2011) recorded significantly higher seed cotton yield $\left(2795 \mathrm{~kg} \mathrm{ha}^{-1}\right)$ and leaf area index with MRC 7361over Bioseed 6488 and RCH 134 hybrids. At Dharwad, Karnataka, Hosmath (2011) recorded significantly higher seed cotton yield $\left(2483 \mathrm{~kg} \mathrm{ha}^{-1}\right)$ with Neeraja (BG II). ACH-155 (3533 kg ha ${ }^{-1}$ ), and Ankur Jai Bt (3380) and Tulasi 117 Bt (3353 kg ha $\left.{ }^{-1}\right)$ also fared better in Maharashtra (Jatav and Shastry, 2011). At Nagpur, Venugopalan et al., (2012) reported superiority of RCH $2 B t$ $\left(1130 \mathrm{~kg} \mathrm{ha}^{-1}\right)$.

Thus, new cultivars are continuously evolved with greater potential, however, a single cultivar cannot perform equally well at all places and varied climatic conditions (Table 1). Therefore, it is essential to assess the potential of new cultivars under varied agroclimatic situations and under extended planting during the season for their plasticity in productivity and reaction to climatic parameters in terms susceptibility to leaf reddening.

\section{Influence of date of sowing}

Crops, cotton being no exception, particularly under rainfed condition need to be sown early in the season with the onset of monsoon to make better use of moist period. Similarly, under irrigated condition though moisture is not a constraint crop essentially need to be planted early in the season to make best use of growing conditions to realize potential yields. However, often due many unpredictable reasons cultivator is forced to sow the crop late and hence it becomes necessary to investigate how long the yields remain unaffected under delayed planting situation or how best yields still can be obtained through management techniques.

Out of five planting dates (April 20, April 30, May 10, May 20 and May 30) hybrids (RCH 134, RCH 314 and MRC 6304) sown on April 20 produced higher seed cotton yield $(24.9 \mathrm{q}$ $\left.\mathrm{ha}^{-1}\right)$, the performance, however, was comparable to the crop sown on April 30 (23.5 $\mathrm{q} \mathrm{ha}^{-1}$ ) (Sukhbir Singh, 2010). Similarly, Rajesh Kumar et al., (2014) recorded higher sympodial plant ${ }^{-1}$, bolls plant $^{-1}$, yield plant $^{-1}$, seed cotton yield and lint yield $\mathrm{ha}^{-1}$ in early planting (20 $0^{\text {th }}$ April and $6^{\text {th }}$ May). Zaheer et al., (2014) also obtained significantly higher boll weight $(3.18 \mathrm{~g})$, seed cotton yield $(65.2 \mathrm{~g}$ plant $\left.^{-1}, 2711 \mathrm{~kg} \mathrm{ha}{ }^{-1}\right)$, seed index $(7.7 \mathrm{~g})$, staple length $(27.60 \mathrm{~mm})$, and seed oil content (20.58\%) from $1^{\text {st }}$ May sown crop.

If Egyptian cotton, Elayan et al., (2015) found that delaying planting pushed cotton plants for an early flowering and maturity with fewer number of days to first open flower and first open boll and the seed cotton yields decreased consistently with each 15-days' delay in planting due to a significant decrease in each open boll plant ${ }^{-1}$ and boll weight. The response to delay of planting was negative with quadratic and linear functions in the first and second seasons, respectively. The delay of planting was associated with a significant deterioration in fibre length and strength and hence lea count strength product and yarn elongation during both seasons. In the TBP irrigation command Pyati (2016) obtained significantly higher dry matter accumulation in leaves, stems and reproductive parts with transplanting/dibbling $B t$ cotton during $1^{\text {st }}$ 
fortnight of June due early and faster accumulation of heat units. Similar was the finding of other workers (Table 2).

Thus, the response to delayed planting was negative with reduction in seed cotton yield associated with a significant deterioration in fibre length and strength. Probably delayed planting pushed cotton plants for an early flowering and maturity expressed in less number of days to first open flower and first open boll and the seed cotton yields per plant. However, responses may vary among locations, and in regions where few heat units accumulate early in the season, earlier planting appears to be of little benefit, while earlier planting may increase yields when a significantly larger amount of heat units accumulate near planting.

\section{Response to seedling transplanting}

Transplanting is common in vegetables and cereals like paddy. But it is one important climate smart technique which helps to overcome the problems of late planting and also helps to make use of available resources at the disposal of grower. Therefore, only recently some researchers have studied the possibility of transplanting and its impact on cotton crop performance.

Dong et al., (2005) found that the seed cotton yield and seed yield were significantly higher in transplanting system (3121 kg ha ${ }^{-1}$ and $1763 \mathrm{~kg} \mathrm{ha}^{-1}$, respectively) than under normal planting (2825 kg ha ${ }^{-1}$ and $1590 \mathrm{~kg} \mathrm{ha}^{-1}$, respectively) and early planting (2497 $\mathrm{kg} \mathrm{ha}^{-1}$ and $1398 \mathrm{~kg} \mathrm{ha}^{-1}$, respectively). Therefore, they suggested that transplanting is a better technique of plant establishment. Rajakumar and Gurumurthy (2008) found that direct seeding recorded a boll setting percentage of 30.29 as against 33.43 per cent under planting through poly bag seedlings which resulted in higher seed cotton yield (2253 kg ha $\left.{ }^{-1}\right)$. In UKP, Karnataka, Salakinkop (2009) obtained
17 to $25 \%$ higher seed cotton yield (3.86 to $4.26 \mathrm{t} \mathrm{ha}^{-1}$ ) from transplanting of seedlings over farmers' practice of dibbling (3.27 tha $\left.{ }^{1}\right)$. Further, leaf reddening also decreased (7.8 to $9.2 \%$ ) under transplanting compared to dibbled crop (19\%).

Transplanting of 20 days old polythene bag nursery grown in FYM: Soil (1:1 mixture) recorded highest yield (3 $336 \mathrm{~kg} \mathrm{ha}^{-1}$ ), however, direct sown crop on April 24 (3 $521.2 \mathrm{~kg} \mathrm{ha}^{-1}$ ) and May 5 (3 $390 \mathrm{~kg} \mathrm{ha}^{-1}$ ) were comparable (Kulvir singh et al., 2009). In UKP irrigation command, Karnataka, Honnali and Chittapur (2013) observed that transplanting at $90 \mathrm{~cm} \times 90 \mathrm{~cm}$ spacing was advantageous (1840 $\mathrm{kg} \mathrm{ha}^{-1}$ ).

Thus, transplanting helps in making best use of pre-season growing time, other farm resources and labour. When such nursery raised seedlings are planted in the season/early in the season by making use of local water avenues, the seedlings take time lead of almost over a month's period over the crop sown with the onset of monsoon/release of canal water in the irrigation commands by continuing from where they have stopped in the nursery. This ensures best use of the time besides making a summer crop possible in irrigated areas. And, cotton also likely to escapes the impact of reddening.

\section{Response to nutrition}

Sound nutrition is one of the ingredients of high yields in cotton. Nutrition affects the yields of cotton to a greater extent than its quality. Fruiting efficiency (ratio of boll/dry weight of stems) is one important yield parameters influenced by the nutrients. $\mathrm{P}, \mathrm{K}$, $\mathrm{Ca}, \mathrm{Mg}, \mathrm{B}$ and $\mathrm{Zn}$ have direct influence on fruit growth while $\mathrm{N}, \mathrm{S}$, Mo and Mn have equal influence on vegetative and reproductive growth. In the country, all cotton growing areas are very poor in organic carbon and $\mathrm{N}$, soils are also poor in available $\mathrm{P}$ and 
medium to high in available $\mathrm{K}$, and hence, adequate fertilization based on crop requirement and soil supply capacity needs emphasis for profitable and sustained production.

At Dharwad, Hosmath et al., (2004) revealed significantly higher cotton yield with RDF + FYM (1169 kg ha $\left.{ }^{-1}\right)$ and FYM (1169 kg ha-1) compared to RDF (938 $\left.\mathrm{kg} \mathrm{ha}^{-1}\right)$, vermicompost $\left(854 \mathrm{~kg} \mathrm{ha}^{-1}\right)$, vermicompost + $\mathrm{RDF}\left(829 \mathrm{~kg} \mathrm{ha}^{-1}\right), \mathrm{RDF}+$ green manure $(785$ $\left.\mathrm{kg} \mathrm{ha}^{-1}\right)$ and green manure alone $\left(713 \mathrm{~kg} \mathrm{ha}^{-1}\right)$ on black soils. While at CICR, Coimbatore, Sankarnarayan et al., (2004) obtained significantly higher opened bolls plant ${ }^{-1}$ and seed cotton $\left(1710 \mathrm{~kg} \mathrm{ha}^{-1}\right)$ with $150 \% \mathrm{RDF}$ which was on par with $125 \%$ of RDF.

Reddy and Kumar (2010) at Warangal, Andhra Pradesh, indicated that cv. Brahma responded positively with a higher level of $250 \mathrm{~kg} \mathrm{~N} \mathrm{ha}^{-1}$ (3628 $\mathrm{kg} \mathrm{ha}^{-1}$ ) compared to lower levels of $\mathrm{N}$ (150 and $200 \mathrm{~kg} \mathrm{ha}^{-1}$ ), whereas application of $60 \mathrm{~kg} \mathrm{P}_{2} \mathrm{O}_{5}$ and $\mathrm{K}_{2} 0 \mathrm{ha}$ 1 recorded significantly higher seed cotton yield over $30 \mathrm{~kg} \mathrm{ha}^{-1}$ while, Saleem et al., (2010) at Faziabad observed highest seed cotton yield (3002 $\left.\mathrm{kg} \mathrm{ha}^{-1}\right)$ with application of $180 \mathrm{~kg} \mathrm{~N} \mathrm{ha}^{-1}$.

Singh et al., (2010) at Pali-Marvar revealed progressive increase in the nitrogen levels up to $200 \mathrm{~kg} \mathrm{ha}^{-1}$ increased the bolls plant (73.0), boll weight (3.24) and seed cotton yield $\left(3080 \mathrm{~kg} \mathrm{ha}^{-1}\right)$ and it was on par with $160 \mathrm{~kg} \mathrm{~N} \mathrm{ha}^{-1}$. At Coimbatore, Nalayani et al., (2010) observed significant response the graded levels of $\mathrm{N}$ and $\mathrm{P}$ while application of RDNP recorded significantly higher plant height, leaf area index, dry matter plant ${ }^{-1}$, good opened bolls plant ${ }^{-1}$, boll weight and seed cotton yield $\left(2300 \mathrm{~kg} \mathrm{ha}^{-1}\right)$. At New Delhi, higher seed cotton yield was observed with application of $35 \mathrm{~kg} \mathrm{P} \mathrm{ha}^{-1}$ compared to $17.5 \mathrm{~kg} \mathrm{P} \mathrm{ha}^{-1}$ (Saleem et al., 2010).
Application of $240: 150 \mathrm{~kg} \mathrm{NK} \mathrm{ha}^{-1}$ with plant density of 7.5 plants $\mathrm{m}^{-2}$ recorded significantly higher seed cotton yield (1545 and $2158 \mathrm{~kg} \mathrm{ha}^{-1}$, respectively) at low and high fertility fields (Dong et al., 2010). While, Kaur et al., (2010) concluded that the application of $125 \%$ recommended dose of fertilizer (187.5:37.5:37.5 NPK $\mathrm{kg} \mathrm{ha}^{-1}$ ) produced significantly higher seed cotton yield $\left(2813 \quad \mathrm{~kg} \mathrm{ha}^{-1}\right)$ compared to recommended fertilizer (150:30:30 NPK kg $\left.h^{-1}\right)$. Tayade and Dhoble (2010) observed increase in growth attributes (plant height, sympodial branches plant ${ }^{-1}$, leaf area and dry matter accumulation plant ${ }^{-1}$ ) and seed cotton yield with the application of 80:40:40 and 100:50:50 kg ha ${ }^{-1}$ NPK.

At Raichur, Karnataka, Biradar et al., (2010) observed significant improvement in seed cotton yield with increase in fertilizer levels up to $150 \%$ and it was 2195 and $2420 \mathrm{~kg} \mathrm{ha}^{-1}$ at 100 and $150 \% \mathrm{RDF}$, respectively with an increase of $10.2 \%$ over RDF. While at Akola, Bhalerao and Gaikwad (2010) obtained significantly higher seed cotton yield $(910 \mathrm{~kg}$ $\left.\mathrm{ha}^{-1}\right)$, bolls plant ${ }^{-1}$ (22.1) and stalk yield (1650 $\mathrm{kg} \mathrm{ha}^{-1}$ ) with $125 \%$ RDF (62.5:31.5:31.5 kg NPK ha ${ }^{-1}$ ) than with $75 \%$ RDF.

Further, Bhalerao et al., (2012) obtained maximum cotton yield plant $^{-1}$ and number of bolls plant ${ }^{-1}$ with $150 \%$ RDF which was at par with $125 \%$ RDF.

Majid and Mohammad (2011) also reported increase in yield with increase in $\mathrm{N}$ level and they recorded the highest seed cotton yield (4363 kg ha ${ }^{-1}$ ) with $200 \mathrm{~kg} \mathrm{ha}^{-1} \mathrm{~N}$, further increase to $300 \mathrm{~N} \mathrm{~kg} \mathrm{ha}^{-1}$ was not useful. At Sriganganagar on loamy soil, Nehra and Yadav (2011) observed significantly higher number of bolls plant ${ }^{-1}$ (129), boll weight (4.41g) and seed cotton yield $\left(3213 \mathrm{~kg} \mathrm{ha}^{-1}\right)$ with application of $125 \%$ RDF (182.5:50 kg $\mathrm{NP} \mathrm{ha}^{-1}$ ) over $75 \% \mathrm{RDF}$ and RDF. 
At Coimbatore, Rajendran et al., (2011) observed that 150:80:80 NPK kg ha ${ }^{-1}$ induced significantly higher dry matter production (4624 kg ha ${ }^{-1}$ ), number of bolls (34.06 plant $\left.{ }^{1}\right)$, boll weight (5.41 g) and seed cotton yield (2411 kg ha ${ }^{-1}$ ) compared to $120: 60: 60 \mathrm{~kg}$ NPK ha ${ }^{-1}$ (2164 kg ha-1). Similarly, Devraj et al., (2011) reported highest seed cotton yield (3061 kg ha $\mathrm{kg}^{-1}$ and $3902 \mathrm{~kg} \mathrm{ha}^{-1}$ at Hissar and Sirsa, respectively) with $125 \%$ RDF (187.5:75:75 NPK ha $^{-1}$ ) compared to $75 \%$ RDF and RDF at both the locations. At Nagpur, Maharashtra, Amboti and Thakare (2012) reported that application of $150 \%$ RDF produced significantly higher seed cotton yield (1.9 $1 \mathrm{ha}^{-1}$ ) and biomass yield (2.46 $\mathrm{t} \mathrm{ha}^{-1}$ ) compared to lower levels of fertilizers. At Junagadh, Gujarat, seed cotton yield increased with application of 240:50:120 kg NPK ha ${ }^{-1}$ to the tune of 20.51 , 6.90 and $13.27 \%$ compared to $120: 50: 120$; 180:50:120 kg NPK $\mathrm{ha}^{-1}$ and control, respectively (Modhvadia et al., 2012). On vertisols, at Parbhani, Maharashtra Asewar et al., (2013) recorded higher seed cotton yield (2864 kg ha ${ }^{-1}$ ) with 200:100:100 kg NPK ha-1.

In Tunga Bhadra irrigation command, Karnataka, Basavaneppa (2012) observed maximum plant height, monopodia, and sympodia per plant with 200:100:100 kg NPK $\mathrm{ha}^{-1}$ and it was at par with 160:80:80 $\mathrm{kg}$ NPK $\mathrm{ha}^{-1}$. Corresponding to higher seed cotton yield $\left(2515 \mathrm{~kg} \mathrm{ha}^{-1}\right)$, higher yield per plant $(135.8 \mathrm{~g})$ and boll weight $(5.09 \mathrm{~g})$ were recorded with 180:90:90 $\mathrm{kg}^{\mathrm{NPK}} \mathrm{ha}^{-1}$. While at Raichur in the same command, Hosamani et al., (2013a) obtained significantly higher seed cotton yield (1925 kg ha ${ }^{-1}$ and $106.92 \mathrm{~g}$ plant $\left.^{-1}\right)$, mean boll weight $(4.13 \mathrm{~g})$, total number of bolls (26.19 plant $\left.^{-1}\right)$, number of good opened bolls (22.15), and lowest bad opened bolls $\left(4.02\right.$ plant $\left.^{-1}\right)$ with the application of $125 \%$ RDF over RDF (17.04 q $\mathrm{ha}^{-1}, 94.86 \mathrm{~g} \mathrm{plant}^{-1}, 3.89,24.42,20.14,4.31 \mathrm{~g}$, respectively).

Table.1 Advantages of $B t$ cotton over other hybrids

\begin{tabular}{|c|c|c|}
\hline Character & Place & Reference \\
\hline \multirow[t]{8}{*}{ Higher yield } & All over India & $\begin{array}{l}\text { Anon. (2002), Khadi et al., (2002), Udikeri et al., (2003a), } \\
\text { Kengegoud (2003), Hosmath et al.,(2004), Sudha (2011) }\end{array}$ \\
\hline & Coimbatore & Manikarn et al.,(2009) \\
\hline & Nagpur & Venugopalan (2002) \\
\hline & Ludhiana & Sukhbir Singh (2010) \\
\hline & New Delhi & Ahlawat and Gangaiah (2010), Gujar et al., (2011) \\
\hline & Raichur & Manjunath et al., (2010a) \\
\hline & China & Qaim and Zilberman (2002) \\
\hline & Australia & Fitt and Roush (2003) \\
\hline \multirow[t]{2}{*}{ Insect tolerance/resistance } & China & Wu et al., (2000), \\
\hline & India & $\begin{array}{l}\text { Udikeri (2003b), Hegde et al., (2004), Vennilla et al., (2004), } \\
\text { Bhosle et al.,(2004), Surulivelu et al., (2004) }\end{array}$ \\
\hline \multirow[t]{2}{*}{ Earliness } & & Jagvirsingh et al., (2003) \\
\hline & & Mayee et al., (2004) \\
\hline Economic profitability & & Patil et al., (2004), Mehta et al., (2009) \\
\hline \multirow[t]{8}{*}{ Better quality lint } & Guntur & Chandrasekhar Reddy (2005) \\
\hline & Dharwad & Khadi et al., (2008), Udikeri et al., (2011) \\
\hline & Raichur & Anand et al., (2009), Manjunath et al., (2010) \\
\hline & Punjab & Pankaj (2009) \\
\hline & Nagpur & Palve et al., (2009). Singh et al., (2011) \\
\hline & Nanded & Phad et al., (2009a) \\
\hline & Parbhani & Chinchane et al., (2009) \\
\hline & Coimbatore & Rajarathinam et al., (2011) \\
\hline
\end{tabular}


Table.2 Response of $B t$ cotton to time of planting

\begin{tabular}{lll}
\hline Planting time & Location & Reference \\
\hline $20^{\text {th }}$ April & Ludhiana & Sukhbir singh (2010), Rajesh kumar et al., (2014) \\
May $3^{\text {rd }}$ week & Semiarid and arid regions & Ikbal et al., (2012) \\
June I I $^{\text {st }}$ fortnight & Raichur & Pyati (2016), Hosamani (2017) \\
\hline
\end{tabular}

Table.3 Response of $B t$ cotton to fertilizer doses at different locations in India

\begin{tabular}{lccl}
\hline Location & $\begin{array}{c}\text { Nutrient applied } \\
\left(\mathrm{N}, \mathrm{P}_{2} \mathrm{O}_{5} \& \mathrm{~K}_{2} \mathrm{O} \mathrm{kg} \mathrm{ha}\right. \\
\end{array}$ & $\begin{array}{c}\text { Yield } \\
\left(\mathrm{kg} \mathrm{ha}^{-1}\right)\end{array}$ & Reference \\
\hline Dharwad & $150: 75: 75+\mathrm{fym} 10 \mathrm{tha}^{-1}$ & 1160 & Hosmath et al., (2004) \\
Coimbatore & $150 \% \mathrm{RDF}$ & 1710 & Sankaranarayan et al., (2004) \\
Ludhiana & $187.5: 37.5: 37.5$ & 3745 & Kaur et al., (2007) \\
Parabhani & $120: 60: 60$ & 2183 & Doli et al., (2009) \\
Raichur & $150: 75: 75$ & 2953 & Ghongane et al., (2009b) \\
Nandyal & $150: 75: 75$ & 1942 & Aruna and Reddy (2009) \\
Warngal & $150: 60: 60$ & 3628 & Reddy and Kumar $(2010)$ \\
Akola & $62.5: 31.5: 31.5$ & 1650 & Balerao and Gaikwad (2010) \\
Siganganagar & $182.5: 50: 0$ & 3213 & Nehra and Yadav (2011) \\
Coimbatore & $150: 80: 80$ & 2411 & Rajendran et al., (2011) \\
Hisar/Sirsa & $187.5: 75: 75$ & $3061-3902$ & Devraj et al., (2011) \\
Parbhani & $200: 100: 100$ & 2864 & Asewar et al., (2013) \\
Siruguppa & $200: 100: 100$ & 2515 & Basavenneppa (2012) \\
\hline
\end{tabular}

Table.4 Response of $B t$ cotton to foliar nutrition

\begin{tabular}{|c|c|c|}
\hline Location & Nutrient suggested & Reference \\
\hline Guntur & $\mathrm{KNO}_{3}(2 \%), 4$ sprays & Kumar et al., 2011) \\
\hline Bangalore & DAP $(2 \%)$ and $\mathrm{KCl}(2 \%)$ at $60 \& 75 \mathrm{DAS}$ & $\begin{array}{l}\text { Chellaiah and } \\
\text { Gopalswamy (2000) }\end{array}$ \\
\hline TBP command & $\mathrm{KNO}_{3} 1 \%$ at flowering and boll development & $\begin{array}{l}\text { Basavanneppa et al., } \\
\text { (2015) }\end{array}$ \\
\hline UKP command & $\begin{array}{l}\text { 19:19:19 }(1 \%) \text { and } \mathrm{MgSO}_{4}(1 \%) \text { at } 80,105 \& \\
\text { 130 DAS }\end{array}$ & $\begin{array}{l}\text { Honnali and Chittapur } \\
\text { (2017) }\end{array}$ \\
\hline TBP command & $1 \% \mathrm{KH}_{2} \mathrm{PO}_{4}$ at $60,80 \& 100$ days after sowing & Basavaraj (2017) \\
\hline
\end{tabular}

Table.5 Yield targets set and nutrients applied at different locations in India

\begin{tabular}{lcll}
\hline \multicolumn{1}{c}{ Place } & $\begin{array}{c}\text { Yield Target } \\
\left(\mathrm{t} \mathrm{ha}^{-1}\right)\end{array}$ & \multicolumn{1}{c}{$\begin{array}{c}\text { Fertilizer applied } \\
\left(\mathrm{N}, \mathrm{P}_{2} \mathrm{O}_{5}, \mathrm{~K}_{2} \mathrm{O} \mathrm{kg} \mathrm{ha}{ }^{-1}\right)\end{array}$} & \multicolumn{1}{c}{ Reference } \\
\hline Rahuri & $1.2-1.6$ & $86: 61: 12(\mathrm{STCR})$ & Sonar et al.,(1984) \\
Coimbatore & 2.5 & $50: 0: 0(\mathrm{STCR})$ & Basu (1995) \\
Siruguppa & 2.5 & $130: 70: 120(\mathrm{SSNM})$ & Biradar and Aladkatti (2005) \\
Dharwad & 3 & $217: 59: 148(\mathrm{SSNM})$ & Police Patil (2007) \\
Raichur & 4 & $195: 100: 200(\mathrm{SSNM})$ & Manjunath et al., (2014) \\
& 5 & $400: 140: 142.5(\mathrm{SSNM})$ & Pyati (2016) \\
Raichur & 5 & $400: 105: 190(\mathrm{SSNM})$ & Hosamani (2017) \\
Yadagiri & 6 & $480: 168: 171(\mathrm{SSNM})$ & Shivaraja (2015) \\
\hline
\end{tabular}


At Dharwad under rainfed condition Gundlur et al., (2013) revealed that growth, yield parameters and yield $\left(2303 \mathrm{~kg} \mathrm{ha}^{-1}\right)$ were significantly improved particularly with 175 \% RDF compared to RDF (1986 kg ha-1). While, Thimmareddy et al., (2013b) obtained significantly higher ginning percentage (35.2\%), lint index (5.6) and fibre length $(32.82 \mathrm{~mm})$ with $150 \%$ RDF over RDF alone (32.77\%, 4.05, $31.68 \mathrm{~mm}$, respectively), however, it was at par with $125 \% \mathrm{RDF}$.

Seed cotton yield was also significantly influenced by varied levels of potassium fertilizer. Application of $90 \mathrm{~kg} \mathrm{ha}^{-1}$ recorded higher plant height $(137 \mathrm{~cm})$, dry matter per plant (401.2g), bolls per plant (85.9) and seed cotton yield $\left(2554 \mathrm{~kg} \mathrm{ha}^{-1}\right)$ compared to lower levels of potassium (Mohan Das et al., 2013). Gangaiah and Ahlawat (2014) at New Delhi observed that application of $180 \mathrm{~kg} \mathrm{~N} \mathrm{ha}^{-1}$ produced significantly higher plant height $(127 \mathrm{~cm})$, LAI (3.87), no. of bolls per plant (54.0) and seed cotton yield (2980 kg ha $\left.{ }^{-1}\right)$ over other nitrogen levels. Munir et al., (2015) also obtained higher seed cotton yield (2197 and $2032 \mathrm{~kg} \mathrm{ha}^{-1}$ in 2007 and 2008, respectively) with $180 \mathrm{~kg} \mathrm{~N} \mathrm{ha}^{-1}$ which was at par with $120 \mathrm{~kg} \mathrm{~N} \mathrm{ha}^{-1}$.

In all, under irrigated condition crop responded to fertilizer application exceeding $150 \mathrm{~kg} \mathrm{~N}$ and $50 \mathrm{~kg}$ each of $\mathrm{P}_{2} \mathrm{O}_{5}$ and $\mathrm{K}_{2} \mathrm{O}$ ha 1 while under rainfed condition the doses could exceed 100:50:50 kg ha $\mathrm{kPK}^{-1} \mathrm{ha}^{-1}$ (Table 3) with potential cultivars and on heavy/productive soils the responses would always be better.

\section{Foliar Nutrition}

Not much information is available on foliar nutrition. Roberts et al., (1997) reported that foliar applied potassium $(\mathrm{K})$ for cotton was profitable in Tennessee studies on low $\mathrm{K}$ soil with fast-fruiting, and high yielding cultivars.
$\mathrm{K}$ deficiencies can be corrected by foliar $\mathrm{KNO}_{3}$ and they found that lint yields responded to $\mathrm{K}$ in foliar $\mathrm{KNO}_{3}$ rather than the N. Harris and Brown (2000) reported that foliar feeding of nitrogen, phosphorus, potassium and boron was most effective when done during peak bloom period. Similarly in Karnataka, Chellaiah and Gopalaswamy (2000) observed response to foliar spray of DAP $(2 \%)+\mathrm{KCl}(1 \%)$ solution at 60 and 75 DAS. Waraich et al., (2011) reported that the foliar application of potassium resulted in increased number of bolls, boll weight and yield plant $^{-1}$.

Kumar et al., (2011) suggested 4 foliar spray of $\mathrm{KNO}_{3}(2 \%)$, whereas, at Guntur Narayana et al., (2011) revealed that 2 sprays of $\mathrm{KNO}_{3}$ (2\%) each at flowering and boll development stage are enough. More recently, in TBP irrigation command, Basavanneppa et al., (2015) found that foliar spray of $\mathrm{KNO}_{3}(1 \%)$ each at flowering and boll development stages recorded significantly higher seed cotton yield $\left(2178 \mathrm{~kg} \mathrm{ha}^{-1}\right)$, net return (Rs.51182 $\mathrm{ha}^{-1}$ ) and $\mathrm{B}$ : C ratio (2:50) compared to only water spray $\left(1903 \mathrm{~kg} \mathrm{ha}^{-1}\right)$ or split application of MOP at $25 \%$ each at sowing, thinning, flowering and boll development stage. While, in UKP irrigation command at Bheemarayanagudi, Karnataka, Honnali and Chittapur (2017) observed that three foliar sprays each of 1.0\% $\mathrm{MgSO}_{4}$ and 19:19:19 at 80, 105 and 130 days after sowing coinciding with square formation, peak flowering and boll development alongwith application of 150:75:75 $\mathrm{kg}^{-1} \mathrm{~N}, \mathrm{P}_{2} \mathrm{O}_{5}$ and $\mathrm{K}_{2} \mathrm{O}$ and soil application of $25 \mathrm{~kg} \mathrm{ha}^{-1} \mathrm{MgSO}_{4}$ at planting recorded higher seed cotton yield $\left(2.07 \mathrm{t} \mathrm{ha}^{-1}\right)$, sustainability yield index $(90.59 \%)$ and economics (Rs. $73630 \mathrm{ha}^{-1}$ and 2.65 net returns and $\mathrm{B}: \mathrm{C}$ ratio, respectively) in comparison to application of recommended dose of fertilizer $(0.87,1.63,70.41 \%$, Rs. 57 380 and 2.38, respectively). Very recently, reduction in leaf reddening and improvement 
cotton yield was reported with foliar spray of $1 \% \quad 4$ at $60,80 \& 100$ days after sowing (Basavaraj, 2017).

All these workers attributed yield responses to better absorption and utilization of foliar applied nutrients at critical stages of cotton growth (Table 4).

\section{Nutrient management for targeted yields}

Cotton, particularly the hybrids are soil exhaustive and, therefore, require heavy nutrient supplementation. Nutrient requirement varies with cultivars, growing conditions and management practices, crop response and yield target. Of late, in the era of precision agriculture the concept of 'fertilizing the crop' is much important than 'fertilizing the soil' which has led from blanket recommendation to soil test based (Soil Test based Crop Response/STCR) or site specific (Site Specific Nutrient Management/SSNM) nutrition for preset target yields is gaining momentum. For achieving a definite yield target of a crop, a definite quantity of nutrients must be applied to the crop and this requirement of nutrients can be calculated by taking into consideration the contribution of soil available nutrients and fertilizer nutrients for total uptake. This forms the basis for the fertilizer recommendation for targeted yield of crops (Subba Rao and Srivastava, 2001). While, SSNM approach focuses on balanced and crop need-based nutrient application (Johnston et al., 2009).

Site specific nutrient management is an approach for the timely application of fertilizers at optimal rates to fill the deficit between the nutrient needs of a high-yielding crop and the nutrient supply from naturally occurring indigenous sources, including soil, crop residues, manures and irrigation water. Hence, the results of experiments of target yield based nutrition are briefed hereunder.
Mizaev and Mamadaliev (1980) at Andizhan region of Uzbekistan indicated that average seed cotton yields of cotton were $3.68 \mathrm{t} \mathrm{ha}^{-1}$ without NPK, $5.08 \mathrm{t} \mathrm{ha}^{-1}$ with recommended rates of NPK and $5.7 \mathrm{t} \mathrm{ha}^{-1}$ with NPK rates calculated for a targeted yield of $6 \mathrm{t} \mathrm{ha}^{-1}$. The uptake of $60 \mathrm{~kg} \mathrm{~N}, 20 \mathrm{~kg} \mathrm{P}_{2} \mathrm{O}_{5}$ and $60 \mathrm{~kg} \mathrm{~K}_{2} \mathrm{O}$ $\mathrm{ha}^{-1}$ seed cotton was the basis for calculating fertilizer rates together with a consideration of the coefficient of utilization of nutrients from soil and the fertilizer.

In India, fertilizer adjustment equations have been developed for cotton based on soil test crop response (STCR). Studies at Rahuri, Maharashtra with yield targets of 1.2 to $1.6 \mathrm{t}$ ha $^{-1}$ (Sonar et al., 1984) revealed higher returns and comparable yields with 86:61:12 $\mathrm{N}, \mathrm{P}_{2} \mathrm{O}_{5}$ and $\mathrm{K}_{2} \mathrm{O} \mathrm{kg} \mathrm{ha}{ }^{-1}$. On the other hand at Coimbatore target yield of $2.5 \mathrm{t} \mathrm{ha}^{-1}$ was obtained with 50:0:0 NPK $\mathrm{kg} \mathrm{ha}^{-1}$ based on fertilizer adjustment equation against blanket recommendation of 90:45:45 NPK kg ha ${ }^{-1}$ (Basu, 1995). This reveals the possibility of saving in chemical fertilizer if contribution of soil is taken into consideration.

On medium to deep black soil at, Parbhani, Maharashtra targeted yields of cotton were in close agreement with actual yields of cotton (Khandare et al., 2002). Therefore, it was concluded that fertilizer prescription equation would be useful to adopt balanced fertilizer dose based on target yield concept in cotton. At Central Cotton Research Farm, Sreepur and, Jagdishpur, Bangladesh, Islam and Mian (2004) developed potassium fertilizer prescription equation for making fertilizer recommendations using data on cotton yield, soil available potassium and potassium fertilizer applied for calculating contribution from soil and applied fertilizer. Kalaichelvi and Chinnusamy (2004) studied the influence of STCR based fertilizer nutrients and potassium humate on cotton productivity and reported that application of $100 \%$ STCR 
recommended NPK fertilizers recorded more number of sympodial branches, fruiting points, boll setting percentage and boll number over other levels. Higher seed cotton yield was recorded with $100 \%$ STCR recommended NPK fertilizer combined with the soil application of potassium humate either $30 \mathrm{~kg}$ or $40 \mathrm{~kg} \mathrm{ha}^{-1}$. Bronson et al., (2006) at Texas, USA, reported that nitrogen management effect on lint yields was highly significant, but the magnitude of the response was less than that of irrigation. Variable rate of $\mathrm{N}$ resulted in more consistent $(1100 \mathrm{~kg}$ lint $\mathrm{ha}^{-1}$ ) lint yield response than did blanket rate $\mathrm{N}$.

Critical nutrient from the point of nutrition for an area is identified through omission plot technique which helps in ascertaining the key nutrient which greatly influences plant performance in a particular area and specific crop so that its supply could be considered on priority under resource constraints. Further, SSNM helps in nutrient supply based on soil supply, fertilizer contribution and crop requirement for a pre-defined crop yield and thereby helps in efficient utilization of both natural and fertilizer resources and also ensures production economy. Therefore, this technique which is superior to blanket recommendation is being used in different crops and farming situations of late.

Doberman et al., (1999) reported that SSNM improved the plant uptake of $\mathrm{N}, \mathrm{P}$ and $\mathrm{K}$ by 10 to $20 \%$ and $\mathrm{N}$ use efficiency by $40 \%$. Similarly, SSNM approach was developed to increase mineral fertilizer use efficiency and to achieve balanced plant nutrition (Doberman et al., 1999; Witt et al., 1999; and Doberman and Fairhurst, 2000). SSNM approach is one such option which focuses on balanced and crop need-based nutrient application (Johnston et al., 2009). Gill et al., (2008) opined that by adopting the principles of SSNM in India, the present food grain production could be achieved from half of the current irrigated area and rest could be better utilized in crop diversification efforts. This remains true for cotton also. Further, SSNM which advocates need based supply of nutrients ensures application of nutrients at right time in desired quantities by the crop for obtaining set yield targets.

Gonias et al., (2005) observed that leaf phosphorus concentration declined significantly for the P-deficient cotton treatment within 1 week after $\mathrm{P}$ was omitted from the nutrient solution. Membrane leakage also increased significantly by 1 week for the P-deficient treatment compared to the Psufficient plants. At Tamil Nadu Agriculture University, Coimbatore, Rajan et al., (2005) revealed that the omission of $\mathrm{P}$ application did not affect the seed cotton yield. However, the omission of $\mathrm{N}$ and $\mathrm{K}$ significantly reduced the seed cotton yield. Biradar and Aladakatti (2005) from ARS, Siraguppa, Karnataka, reported that 130:70:120 kg ha ${ }^{-1}$ plus the stand suite for secondary and micronutrients produced $2.3 \mathrm{t} \mathrm{ha}^{-1}$. The NPK based RDF and PR treatment produced $2 \mathrm{t} \mathrm{ha}^{-1}$ and $1.9 \mathrm{t} \mathrm{ha}^{-1}$, respectively.

Police Patil et al., (2009) at Dharwad reported improvement in seed cotton yield with increase in the fertilizer levels targeted from 2.0 to $3.0 \mathrm{t} \mathrm{ha}^{-1}$. Improvement in seed cotton yield was in the order of $63.90,15.60$ and 7.30 per cent over their respective target yield levels. Significantly higher seed cotton yield was recorded with 217:59:148 kg NPK ha ${ }^{-1}$ (3219 $\mathrm{kg} \mathrm{ha}^{-1}$ ) level over 145:39:99 NPK kg $\mathrm{ha}^{-1} \quad\left(2738 \mathrm{~kg} \mathrm{ha}^{-1}\right)$ level. However, 217:59:148 NPK kg ha-1 (2891 kg ha ${ }^{-1}$ ) level was on par with 217:59:148 $\mathrm{kg}^{\mathrm{NPK}}$ ha ${ }^{-1}$ level.

At ARS, Siruguppa, Karnataka, Biradar et al., (2011) observed that $\mathrm{N}$ omission reduced the seed cotton yield and net income by about 41 
and $50 \%$, respectively followed by omission of $\mathrm{K}$ and $\mathrm{P}$. Omission of $\mathrm{N}$ also resulted in lower net income compared to other nutrients. Similar was the finding of Chittapur et al., (2017) in TBP command. However, omission of secondary nutrients such as $\mathrm{Ca}, \mathrm{Mg}, \mathrm{S}$, and micronutrients such as $\mathrm{Zn}, \mathrm{Fe}$, and $\mathrm{B}$ had no drastic negative effect on cotton yields. Hence, they concluded that $\mathrm{N}$ followed by $\mathrm{K}$ and $\mathrm{P}$ were the major nutrients contributing to higher yield of $B t$-cotton.

At Raichur, Karnataka, Manjunatha et al., (2014) reported that application of nutrients under assured rainfed condition as per the target yield of $4.0 \mathrm{t} \mathrm{ha}^{-1}$ (195:100:200 NPK kg $\mathrm{ha}^{-1}$ ) recorded significantly higher seed cotton yield (3940 kg ha ${ }^{-1}$ and $234.7 \mathrm{~g}_{\text {plant }}^{-1}$ ). Aladakatti et al., (2012) reported that soil organic carbon decreased in absolute control where no nutrients were applied $(0.50 \%$ to $0.38 \%)$ and also in the $\mathrm{N}$ omission plot $(0.50$ $\%$ to $0.35 \%$ ). But there was no significant impact of omission of $\mathrm{P}, \mathrm{K}$ and other nutrients on soil organic carbon. Soil available N, P and $\mathrm{K}$ were reduced from the initial soil status after first and second crop of cotton in the respective treatments where these nutrients were omitted. The soil available $\mathrm{N}, \mathrm{P}$ and $\mathrm{K}$ were reduced to the extent of $61,7.1 \mathrm{~kg}$ and $161.9 \mathrm{~kg} \mathrm{ha}^{-1}$, respectively in respective nutrient omission treatments at the end of second crop of cotton. Omission of N, P and $\mathrm{K}$ also reduced the seed cotton yield by 41 , 9.3 and $27.3 \%$, respectively.

On farmers' fields in TBP irrigation command while validating SSNM, Chittapur et al., (2017) obtained significantly higher number of bolls plant ${ }^{-1}$, average boll weight and seed cotton yield (4384 kg ha ${ }^{-1}$ ) was recorded with SSNM (for $4 \mathrm{t} \mathrm{ha}^{-1}$ yield target) treatment. Lower values for these attributes were recorded in nitrogen omission treatment (3707 $\mathrm{kg} \mathrm{ha}^{-1}$ ) followed by $\mathrm{K}$ and $\mathrm{P}$ omission treatments.
Thus, the foregoing review reveals that soil testing and fertility management is of great importance to any country for sustained crop production. The STCR or SSNM approach or targeted yield approach is a step ahead in fertilizer recommendation over the prevailing blanket recommendation as these approaches are based on soil fertility class (low, medium and high) and crop requirement (Table 5). Further, it is also clear that with the evolution on new and highly responsive and potential cultivars for commercial use the set yield target has also almost seen four-fold increase over the targets set initially (1.2 to $5.0 \mathrm{t} \mathrm{ha}^{-1}$ ). So far efforts to achieve up to $5 \mathrm{t} \mathrm{ha}^{-1}$ targets were met with success in UKP and TBP commands of Karnataka (Shivaraja, 2015, Pyati, 2016 and Hosamani, 2017). They stressed early planting and supplementation of nutrition through $\mathrm{MgSO}_{4}, 19: 19: 19$ and $\mathrm{KNO}_{3}$ through foliage to manage leaf reddening during critical flowering to boll development period alongwith required NPK it is essential through to realize the set target. Therefore, it is pragmatic to fix yield target looking into the genetic potential of the crop/variety and other factors.

The fore-going review, no doubt, emphasizes the invigoration of Indian cotton production and industry with the advent of $B t$ cotton since 2002. The potential of these hybrids has witnessed quantum jump from one to over six tonnes per ha over years with broadened insect resistance/tolerance due to concerted efforts in biotechnology and plant breeding. However, continued monocropping practice by farmers driven by market is draining soil resources greatly. Besides, the changing climate particularly the delayed monsoon with its impact on soil moisture and heat units is also affecting production. Consequently, crop yields are either stagnating or decreasing. Under these circumstances, screening new cultivars, advancing sowing with available water or transplanting and crop nutrition 
based on soil supply capacity and crop removal for a pre-set yield target $5 \mathrm{t} \mathrm{ha}^{-1}$ ) either through STCR or SSNM hold promise.

\section{References}

Ahlawat, I. P. S., and Gangaiah, B., 2010, Response of Bt cotton (Gossypium hirsutum) hybrids to irrigation. Indian J. Agric. Sci., 80(4): 271-274.

Aladakatti, Y. R., Biradar, D. P., Satyanarayan, T., Majumdar, K. and Shivamurthy, D., 2012, Nutrient omission in Bt cotton affects soil organic carbon and nutrients status, $E G U$ General Assembly 2012, held 22-27 April, 2012 in Vienna, Austria., p.1124.

Amboti, R. R. and Thakare, S. K., 2012, Effect of nutrient management on FUE, red leaf, fibre properties of $\mathrm{Bt}$ hybrid cotton (Gossypium hirsutum). Indian J. Agron., 57(4): 390-396.

Anand, S. R., Ramesh Babu, Ashok, P. and Smitha, R., 2009, Effect of plant spacing on yield and quality parameters of $B t$ cotton (Gossypium hirsutum L.) hybrids in Tungabhadra command area under irrigation. Environ. Ecol., 27(34): 1279-1282.

Anonymous, 2002, Final Rep, Evaluation of $B t$ cotton hybrids Project co-ordinator (cotton). 2001-02, CICR, Coimbatore, India, pp. 25-42

Anonymous, 2006. Project Co-ordinator Report 2006-07, Annual group meeting of AICCRP, CICR, Coimbatore, pp. 81-86.

Aruna, E., and Reddy, B. S., 2009, Response of Bt cotton to plant geometry and nutrient combinations. Indian J. Agric. Res., 43(3): 206-210.

Asewar, B. V., Pawar, S. U., Bhosle, G. P. and Gokhale, D. N., 2013, Effect of spacings and fertilizer levels on seed cotton yield and economics of Bt cotton. J. Cotton Res. Dev., 27(1): 63-65.

Basavaneppa, 2012, Effect of nutrients on endotoxin and management of refuge crops in $B t$ cotton under irrigated condition. Ph. D. Thesis, Uni. Agric. Sci., Dharwad, Karnataka (India).

Basavanneppa, M. A., Ajaykumar, M. Y., Nidagundi, J. M. and Biradar, D. P., 2015, Response of $B t$ cotton to foliar application of potassium nitrate in Tungha Bhadra project area. J. Cotton Res.h and Develop, 29 (2): 242-245.

Basu, A. K., 1995, Current status of cotton research in India. J. Indian. Soc. Cotton. Improv. 20 (1): 14-34.

Bhalerao, P. D., and Gaikwad, G. S., 2010, Productivity and Profitability of $\mathrm{Bt}$ cotton (Gossypium hirsutum) under various plant geometry and fertilizer levels. Indian $J$. Agron., 55(1): 60-63.

Bhalerao, P. D., Deshmukh, P. W., Godavari, Gaikwad, S., 2012, Response of Bt cotton (Gossypium hirsutum) to spacing and fertilizer levels under rainfed condition. Indian J. Agron., 57(2): 176-179.

Bhosle, B. B., Patange, N. R. and Rathod, K. S., 2004, Insecticidal management of key pests in $B t$ cotton. Int. Symp. On 'Strategies for Sustainable Cotton Production - A Global Vision 2, Crop Production, 23-25 Nov., UAS, Dharwad, Karnataka (India), pp. 158160.

Biradar, D. P., Aladakatti, Y. R., Basavanneppa, M. A., Shivamurthy, D. and Satyanarayana, T., 2010. Assessing the contribution of nutrients to maximize transgenic cotton yields in vertisols of Northern Karnataka. Better Crops, 5(1): 22-25.

Biradar, D. P., Aladakatti, Y. R., Basavanneppa, M. A., Shivamurthy, D. and Satyanarayana, T., 2011. Assessing the contribution of nutrients to maximize transgenic cotton yields in vertisols of Northern Karnataka. Better Crops, 5(1): 22-25.

Biradar, D. P., and Aladakatti, Y. R., 2005, Site specific nutrient management for maximisation of crop yields in Northern Karnataka, Indian J. Agric. Sci., 25: 30-38.

Biradar, D. P., and Aladakatti, Y. R., 2005, Site specific nutrient management for maximisation of crop yields in Northern Karnataka, Indian J. Agric. Sci., 25: 30-38.

Bronson, K. F., Booker, J. D., Bordovsky, J. P., Keeling, J. W., Wheeler, T. A., Boman, R. K., Parajulee, M. N., Segarra, E. and Nichols, R. L., 2006, Site specific irrigation and nitrogen management for cotton production in the Southern High Plains. Agron. J., 98: 212-219. 
Chandrasekhar Reddy, M., Siva Reddy, K. V. and Narsi Reddy, A., 2005, Performance of $B t$ cotton in Andhra Pradesh. J. Res. ANGRAU, Hyderabad, 33(4): 79-81.

Chellaiah, N., and Gopalaswamy, N., 2000, Effect of intercropping and foliar nutrition on the productivity of summer irrigated cotton. Madras Agric. J., 87: 267-270.

Chinchane, V. N., Baig, K. S., Unchegaonkar, P. R., Kadam, P. S., Gaikwad, A. R., 2009, Evaluation of $\mathrm{Bt}$ Cotton hybrids under rainfed condition. Nation. Symp. On Bt Cotton: Opportunities and Prospects. 17-19, November, CICR, Nagpur, Maharashtra, P. 13.

Chittapur, B. M., Pyati, P. S., Umesh, M. R., Halepyati, A. S. and Satyanarayanarao, T., 2017, Response of Bt cotton to nutrient omission and site specific nutrient management in vertisols under irrigation. Indian Journal of Ecology, 44 (10): (in press).

Devraj, M. S., Bhattoo, B. S. Duha, Promila Kumari and Jain, P. P, 2011, Effect of crop geometry and fertilizer levels on seed cotton yield and nutrient uptake of $B t$ cotton under irrigated conditions, J. Cotton Res. Dev., 25(2): 176-180.

Doberman, A., and Fairhurst, T., 2000, Rice: Nutrient disorders and nutrient management Potash and Phosphate Institute of Canada and Int. Rice Res. Inst., Singapore and Los Banos, pp. 191.

Doberman, A., Witt, C., Robert, P. C. and Larson, W. E., 1999, SSNM concept for irrigated system. Better Crops International, 16(1): 25: $1-7$.

Doberman, A., Witt, C., Robert, P. C. and Larson, W. E., 1999, SSNM concept for irrigated system. Better Crops International, 16(1): 25: $1-7$

Doli, A. N. M. G., Umate, G. L., Sawargaonkar, M. G. Patil, 2009, Effect of different fertilizer doses and green manuring treatments on growth and yield of rainfed $B t$ cotton. Natl. Symp. On Bt Cotton: Opportunities and Prospects. 17-19, November, CIC, Nagpur, Maharashtra, p. 60.

Dong, H., Kong, X., Weijiang Li, Wei Tang and Zhang, D., 2010, Effects of plant density and nitrogen and potassium fertilization on cotton yield and uptake of major nutrients in two fields with varying fertility. Field Crops Res., 119: 106-113.

Dong, H., Li, W., Li, Z., Tang, W. and Zhang, D., 2005, Evaluation of production systems in China that uses reduced plant densities and retention of vegetative branches. J. Cotton Sci., 9: 1-9.

Elayan, E. D., Sohair, Abdalla, A. M. A. and Abdel Gawad, 2015, Effect of delaying planting date on yield, fiber and yarn quality properties in some cultivars and promising crosses of Egyptian cotton. AmericanEurasian J. Agric. Environ. Sci., 15(5): 754763.

Fitt, G., and Roush, R., 2003, Why Ingard cotton must go. In: TIMS-Transgenic and Insecticide Management Strategy Committee. http://www.cotton.pi. csiro.all/ assets/pdffiles/ingogo.pdf.

Gangaiah, B., and Ahlawat, I. P. S., 2014, Nitrogen fertilization of Bt cotton (Gossypium hirsutum) - wheat (Triticum aestivum) cropping system. Indian J. Agron., 59(2): 235-241.

Ghongane, S. B., Yeledhalli, N. A., Ravi, M. V., Patil, B. V., Desai B. K. and Beledhadi, R., V., 2009b, Effect of fertilizer and irrigation levels on growth, yield and quality of transgenic $B t$ cotton in deep vertisols. Karnataka J. Agric. Sci., 22(4): 905-908.

Gill, M, S., Shukla, A. K. and Pandey, P. S., 2008, Yield, nutrient response and economic analysis of important cropping systems in India. Indian J. Fert., 4(4): 11-38.

Gitte, A. N., Deosarkar, D. B., Patil, D. V. and Gaikwad, A. R., 2009, Physiological efficiency of $B t$ cotton hybrids in relation to growth and yield contributing characters. Natl. Symp. On Bt Cotton: Opportunities and Prospects. 17-19, November, CICR, Nagpur, Maharashtra, p. 51.

Gonias, E., Oosterihuis, D. M., Bibi, A. and Mozaffari, M., 2005, Effect of phosphorus deficiency on cotton physiology. AAES Research Series 537.

Gopalakrishnan, N., Khader, S. E. S. A. and Prakash, A. H., 2009, Effect of elevated carbon dioxide atmosphere on nitrate reductase and photosynthetic activity in $B t$ cotton hybrids. Natl. Symp. On Bt Cotton: 
Opportunities and Prospects. 17-19, November, CICR, Nagpur, Maharashtra, p. 42.

Gujar, G. T., Bunker, G. K., Singh, B. P. and Kalia, V., 2011, Field performance of $F_{1} F_{2}$ and non Bt BG-II (MRC-7017 Bt) and JKCH-1947 Bt against bollworms of cotton. World Cotton Res. Conf-5, Mumbai, India. 711 November, pp. 165-173.

Gundlur, S. S., Rajkumara, S., Neelakanth, J. K., Ashoka, P. and Khot, A. B., 2013, Water and nutrient requirement of $B t$ cotton under vertisols of Malaprabha command. Karnataka J. Agric. Sci., 26(3): 368-371.

Halemani, H. L., Hallikeri, S. S., Nandagavi, R. A. and Nooli, S. S., 2004, Performance of Bt cotton hybrids at different levels of fertilizers under protective irrigation. Int. Symp. on 'Strategies for Sustainable Cotton Production - A Global Vision 2, Crop Production, 23-25 Nov., UAS, Dharwad, Karnataka (India), pp.153-155.

Harris, G. H., and Brown, S. M., 2000, Cotton Newslett, Aug 25.

Hegde, M., Nidagundi, J. M., Biradar, D. P., Udikeri, S. S. and Khadi, B. M., 2004, Performance of $B t$ and non- $B t$ cotton hybrids against insect pests under irrigated condition. Int. Symp. On 'Strategies for Sustainable Cotton Production - A Global Vision 2, Crop Production, 23-25 Nov., UAS, Dharwad, Karnataka (India), pp.

Honnali, S. N., and Chittapur, B. M., 2013, Enhancing Bt Cotton (Gossypium spp.) productivity through transplanting in Upper Krishna Project (UKP) command area of Karnataka. Indian J. Agron, 58 (1): 105-108.

Hosamani, V., Halepyati, A. S., Koppalkar, B. G., Desai, B. K. and Ravi, M. V., 2013a, Yield, quality parameters and uptake of nutrients in irrigated Bt cotton (Gossypium hirsutum L.) as influenced by macro nutrients and liquid fertilizers. Karnataka J. Agric. Sci., 26(3): 421-423.

Hosmath, J. A., 2011, Evaluation of Bt cotton genotypes and nutrient management to control leaf reddening. Ph. D. Thesis, Univ. Agric. Sci., Dharwad, Karnataka (India).

Hosmath, J.A., Biradar, D.P., Deshpande, S.K., Dodamani, S.V., Rizwan, M. D. and Nooli, S.S., 2004, Study of Bt and non-Bt cotton performance in organics and its effect on soil properties and nutrient status. In: International Symposium on "Strategies for Sustainable Cotton Production - A Global Vision" 2. Crop Production, 23-25 November 2004, UAS, Dharwad, Karnataka, India, pp. 135-137.

Iqbal, J., Wajid, S. A., Ahmad, A. and Arshad, M., 2012, Comparative studies on seed cotton yield in relation to planting dates under diverse agro-environment of Punjab. Pakistan J. Agric. Sci., 64(1): 59-63.

Islam, M. K., and Mian, M. H. R., 2004, Potassium fertilizer prescription for targeted yield of cotton. In: International Symposium on "Strategies for Sustainable Cotton Production-A Global Vision" 2. Crop production, 23-25 November 2004, UAS, Dharwad, Karnataka, India. pp. 250.

Jagvir Singh, Shilpa Babar, Shalu Abraham, Venugopalan, M. V, and Majumdar, G., 2003, Fertilization of high density, rainfed cotton grown on vertisols of India. Cotton Res. J., 96(2): 83-86.

Jatav, L., and Shastry, P. P., 2011, Identification of Suitable $B t$ cotton hybrids for rainfed conditions of Malwa Nimar region. J. Cotton Res. Dev., 25(1): 30-32.

Johnston, A.M., H.S. Khurana, K. Majumdar, and T. Satyanarayana. 2009. JISSS 57(1):1-10.

Joshi, P. M., 2007, Agronomic performance in endotoxin quantification and molecular characterization of $B t$-cotton genotypes. $M$. Sc. (Agri.) Thesis, Univ. Agric. Sci., Dharwad, Karnataka (India).

Kalvir Singh, Rupinder Singh and Kuldeep Singh, 2009, Studies on the performance of $B t$ cotton hybrids and biovita for improving productivity. Natl. Symp. On Bt cotton: Opportunities and Prospects. 17-19. November, CICR, Nagpur, Maharashtra, p. 17.

Kaur, P., Buttar, G. S., Kaur, M., Gill, M.S. and Sohu, R.S., 2010, Effect of foliar and split application of potash on seed cotton yield and fibre quality of American cotton (Gossypium hirsutum L.). Indian J. of Agric. Sci., 81(9): 838-842.

Kaur, P., Maninder Kaur, Gill, M. S. and Buttar, G. S., 2007, Response of $B t$ cotton hybrid $\mathrm{RCH} 134$ to varied spacing and fertility 
levels under Punjab conditions. J. Cotton Res. Dev., 24(2): 189-192.

Kengegowda, N., 2003, Studies on the population dynamics and screening of $B t$ cotton hybrids against insect pest. M. Sc. (Agri.) Thesis, Univ. Agric. Sci., Dharwad (India).

Khadi, B. M., Katageri, I. S. and Mogali, S. C., 2008, Performance of $B t$ cotton hybrids for yield and fiber quality in transitional tract of Karnataka (India). Agric. Sci. Digest, 28(4): 283-285.

Khadi, B. M., Katageri, I. S., Kulkarni, V. N. and Badigannavar, A. $\quad$ M., 2002, Evaluation of $B t$ cotton hybrids in transitional tract of Karnataka. In: National Seminar on Bt cotton Scenario with special reference to India, Dharwad, May, 23, p. 87.

Kulvir Singh, Harmandeep Singh, Gumber, R. K. and Pankaj, R., 2011, Studies on the seed cotton yield, growth and yield contributing characters of New $B t$ cotton hybrids under varied agronomic manipulations. In: Proc. World Cotton Res. Conf. On Technologies for Prosperity during November, 7-11, Mumbai, India. pp. 338-340.

Kumar, Jagdish, Arya, K. C. and Siddique, Mohammad Zafar, 2011, Effect of foliar application of $\mathrm{KNO}_{3}$ on growth, yield attributes, yield and economics of hirsutum cotton. J. Cotton Res. Develop., 25: 122-23.

Manjunatha, M. J., Halepyati, A. S., Koppalkar, B. G. and Pujari, B. T., 2010a, Yield and yield components, uptake of nutrients, quality parameters and economics of $B t$ cotton (Gossypium hirsutum L.) genotypes as influenced by different plant densities. Karnataka J. Agric. Sci., 23(3): 423-425.

Manjunatha, M. J., Halepyati, A. S., Koppalkar, B. G. and Pujari, B. T., 2010b, Influence of different plant densities on the growth, yield and economics of $B t$ cotton (Gossypium hirsutum L.) genotypes under dryland condition. Karnataka J. Agric. Sci., 23(4): 580-583.

Manjunatha, S. B., Biradar, D. P. and Aladakatti, Y. R., 2014, Response of $B t$ cotton to nutrients applied based on target yield. Res. Environ. Life Sci., 7(4): 247- 250.

Mayee, C. D., Phundan Singh, Mohan P. and Agarwal, D. K., 2004, Evaluation of Bt transgenic intra hirsutum hybrids for yield and fibre properties. India J. Agric. Sci., 74(1): 46-47.

Mehta, A. K., Saharan, J. S., Thakral, S. K. and Jagdish Beniwal, 2009, Performance of $B t$ cotton hybrids at farmers field in Haryana. $J$. Cotton Res. Dev., 23(2): 243-246.

Mirzaev, O.F. and Mamadaliev, A.K., 1980, A trail on obtaining targeted yield of cotton. Khlopkovodstvo, 2: 21-22.

Mohan Das, Raghavaiah, D. R., Sreenivas, G., Sailaja, V. and Sivasankar, A., 2013, Response of $\mathrm{Bt}$ Cotton hybrid (Gossypium hirsutum) to integrated nitrogen management and potassium. India J. Agron., 58(3): 391395.

Munir, M. K., Tahir, M., Saleem, M. F. and Yaseen, M., 2015, Growth, yield and earliness response of cotton to row spacing and nitrogen management. J. Animal Plant Sci., 25(3): 729-738.

Nehra, P. L., and Yadav, P. S., 2011, Agronomic Evaluvation of $B t$ cotton hybrid (RCH-134 $\mathrm{Bt}$ I) under varied crop geometries and fertilizer levels in canal command area of north-west Rajasthan, Cotton Res. J., 2: 7780.

Palve, S. M., Singh, V. V. and Nita K., 2009, Genetic variation for seed cotton yield, some yield components and fiber properties in $B t$ cotton hybrids (Gossypium. hirsutum L.). Natl. Symp. On Bt cotton: Opportuities and Prospects. 17-19, November, CICR, Nagpur, Maharashtra, p. 1.

Pankaj, R., Gill, J. S., Vikas, J., Satnam, S. and Manpreet, S., 2009, Performance of some Bt cotton hybrids in south-western districts of Punjab. Nation, Symp. On Bt Cotton: Opportunities and Prospects. 17-19, November, CICR, Nagpur, Maharashtra, p. 15.

Patil, B. V., Bheemanna, M., Hanchinal, S. G. and Kengegowda, N., 2004, Performance and economics of $B t$ cotton cultivation in irrigated ecosystem. Int. Symp. On 'Strategies for Sustainable Cotton Production - A Global Vision 2, Crop Production, 23-25 Nov., UAS, Dharwad, Karnataka (India), pp. 139-142.

Patil, S., Patil, B., Babu, A. G., Kademani, S., Bavikatti, S. and Pawar, K. N., 2011, Studies 
on change in the gas exchange and phonological parameters under water stress condition in Bt cotton hybrid. World Cotton Res. Conf. on Technologies for Prosperity-5, Mumbai, 7-11, November 2011, p. 169.

Pawar, K. M., Patil, B. C., Khadi, B. M., Ashtaputre, S. A. and Rajesh Patil, 2009, Assessing physiological efficiency in $B t$ and non $B t$ contton hybrids. Nation. Symp. On Bt cotton: Opportunities and Prospects. 17-19. November, CICR, Nagpur, Maharashtra, p. 61.

Phad, D. S., Bhatade, S. S. and Deosarkar, D. B., $2009 \mathrm{~b}$, Identification of suitable $B t$ cotton hybrids under rainfed condition of Marathwada region. Nation. Symp. On Bt Cotton: Opportunities and Prospects. 17-19, November CICR, Nagpur, Maharashtra, P. 24.

Phad, D. S., Bhatade, S. S. and Deosarkar, D. B., 2010, Identification of suitable Bt cotton hybrids under rainfed condition of Marathwada region, J. Cotton Res. Dev., 24(1) 5-8.

Phad, D. S., Deosarkar, D. B., Bhatade, S. S. and Sarang, D. H. 2009a, Evaluation of Bt cotton hybrids identified for central zone under rainfed conditions. Nation. Symp. On Bt cotton: Opportunities and Prospects. 17-19, November, CICR, Nagpur, Maharashtra, p. 13.

Police Patil, A. S., 2007, Performance of $B t$ cotton hybrids as influenced by site specific nutrient anagement approach for realising target yields. M. Sc, (Agri.) thesis Univ. Agric. Sci., Dharwad, Karnataka (India).

Police Patil, A. S., Chittapur, B. M., Patil, B. N., Hiremath, S. M., Channal, H. T., Koti, R. V. and Udikeri, S. S., 2009, Response of Bt cotton hybrids to site specific nutrient management for targeted yields. Karnataka J. Agric. $\quad$ Sci., $22(1)$ : 188-189.

Poongothai, K., Ilavarasan, R. and Karrunakaran, C. M., 2010, Cryl Ac levels and biochemical variations in $B t$ cotton as influenced by tissue maturity and senescence. J. Plant Breed. Crop Sci., 2(5): 96-103.

Prasad, N. V. V. S. D., and Rao, N. H., 2008, Field evaluation of $B t$ cotton hybrids against insect pest complex under rainfed condition.
Indian J. Ent., 70(4): 330-336.

Pyati, P. S., 2016, Response of Bt cotton (Gossypium hirsutum L.) to method and time of planting, nutrient omission and SSNM in TBP command. M.Sc. (Agri.) Thesis, Univ. Agric. Sci., Raichur, Karnataka.

Qaim, M., and Zilberman, D., 2002, genetically modified crops can have significant yield effects in developing countries. Science, http://are.berkeley.edu/ courses/ are 253/2004/handouts/pdf.

Rajan, A., Janaki, P., Appavu, K. and Vadivel, A., 2005, The effect of N, P and K fertilization with FYM in cotton (Var. KC 2). Madras Agric. J., 92 (4-6): 266-270.

Rajarathinam, S., Vidhiyavarman, P., Pushpa, R. and Malini, 2011, Evaluation of prerelease Bt-cotton hybrids under winter irrigated conditions of Tamil Nadu. World Cotton Res. Conf. On Technologies for Prosperity-5, Mumbai, 7-11, November, p. 193.

Rajarathinam, S., Vidhiyavarman, P., Pushpa, R. and Malini, 2011, Evaluation of prerelease Bt-cotton hybrids under winter irrigated conditions of Tamil Nadu. World Cotton Res. Conf. On Technologies for Prosperity-5, Mumbai, 7-11, November, p. 193.

Rajendran, K., Mohamed, M. A. and Vaiyapuri, K., 2011, Influence on growth, yield attributes and yield of $B t$ cotton by soil and foliar application of nutrients. Madras Agric. J., 98(1-3): 67-68.

Rajesh Kumar, Bhattoo, M. S., Punia, S. S., Nabin and Satbeer Yadav, 2014, Performance of different Bt cotton (Gossypium hirsutum L.) hybrids under varying dates of planting. $J$. Cotton Res. Dev., 20(2): 263-264.

Rajkumar, D., and Gurumurthy, S., 2008, Effect of plant density and nutrient spray on the yield attributes and yield of direct sown and polybag seedling planted hybrid cotton. Agric. Sci. Digest, 28 (3): 174 - 177.

Reddy, P. R., and Kumar, B. D., 2010, Fertilizer response studies in $B t$ cotton hybrid. $J$. Cotton Res. Dev., 24(1): 76-77.

Rekha, G.O., 2007, A comparative assessment of morphophysiological characters and yield in $B t$ and non-Bt cotton hybrids, M.Sc. (Agri.) Thesis. Univ. Agril. Sci., Dharwad, Karnataka (India).

Roberts, R. K., Gerloff, D. C and Howardad, D., 
1997, Foliar potassium on cotton - a profitable supplement to broadcast potassium application on low testing soils. Better Crops, 81(1): 20-23.

Saini, D. P., Kalyan, R. K., Meena P. K. P. and Urmila, 2011, Evaluation of Bt cotton hybrids for yield and quality components. World Cotton Res. Conf.-5. Mumbai, India, 7-11, November, p. 131.

Salakinkoppa, S. R., 2009, enhancing the productivity of irrigated $B t$ cotton (Gossypium hirsutum) by transplanting technique and planting geometry. Indian $J$. Agric. Sci., 81:2

Saleem, M. F., Bilal, M. F., Awais, M., Shahid, N. Q. and Anjum, S. A., 2010, Effect of nitrogen on seed cotton yield and fiber qualities of $B t$ Cotton cultivars. J. Animal Plant Sci., 20(1): 23-27.

Sankarnarayanan, K., Nalayini, P., Praharaj, C. S. and Dharajothi, B., 2004, Effects of dates of sowing on the productivity of $B t$ cotton Hybrids. In: Intl. Symp. On "Strategies for Sustainable Cotton Production-A Global Vision" 2 Crop Production. 23-25 November 2004, Univ. Agric. Sci., Dharwad, Karnataka (India), pp. 103-104.

Sankarnarayanan, K., Nalayini, P., Praharaj, C. S. and Dharajothi, B., 2004, Effects of dates of sowing on the productivity of $B t$ cotton Hybrids. In: Intl. Symp. On "Strategies for Sustainable Cotton Production-A Global Vision" 2 Crop Production. 23-25 November 2004, Univ. Agric. Sci., Dharwad, Karnataka (India), pp. 103-104.

Sarang, D. H., Bhatade, S. S. and Deosarkar, D. B., 2010, Evaluation of some new Bt Cotton hybrids for seed cotton yield and fibre quality parameters under rainfed condition. J. Cotton Res. Dev., 24(1): 28-31.

Sharma, J. K., Vhamparia, S. K., Parsai, G. S., Mishra, U. S. and Mandloi, K. C., 2009, Performance of cotton genotypes in relation to spacing and fertility levels in East Nimar. J. Cotton Res. Develop., 14: 235-7.

Singh, K., Harmandeep Singh, Gomber, R.K and Pankaj Rathore, 2011, Studies on the seed cotton yield, growth and yield contributing characters of new $B t$ cotton hybrids under varied agronomic manipulations. World Cotton Research
Conference on Technologies for prosperity 5, Mumbai, 7-11 November 2011, Book of Papers, p. 338-340.

Singh, S. B., Amol, K. and Bansode, N. V., 2011, Performance of $B t$ hybrids for yield and economic characters World Cotton Res. Conf. On Technologies for Prosperity-5, Mumbai, 7-11, November, p. 127.

Singh, Y., Rao, S. S. and Regar, P. L., 2010, Deficit irrigation and nitrogen effects on seed cotton yield, water productivity and yield response factor in shallow soil of semi-arid environment. Agri. Water Mgt., 97: 965-970.

Sonar, K.R., Shinde, S.S., Khumbar, D.D., Patil, B.P. and Patil, N.D., 1984, Fertilizer requirements of cotton based on targeted yield approach. Cotton Develop, 14 (1): 36-37.

Sonar, K.R., Shinde, S.S., Khumbar, D.D., Patil, B.P. and Patil, N.D., 1984, Fertilizer requirements of cotton based on targeted yield approach. Cotton Develop, 14 (1): 36-37.

Subba Rao, A., and Srivastava, S., 2001, Soil testbased fertilizer recommendations for targeted yield of crops. Indian Inst. Soil Sci., Bhopal, Madhya Pradesh, India, pp. 326.

Sudha, T., 2011, Studies on performance of Bt Cotton genotypes in different soils of northern transition zone of Karnataka under rainfed situation through farmers participatory approach. Ph.D. Thesis. Univ. Agric. Sci., Dharwad, Karnataka (India).

Sukhbir Singh, 2010, Effect of planting dates on growth and yield Bt-cotton hybrids (Gossypium hirsutum L.). Crop Improv, 37(2): 204-208.

Sukhbir Singh, 2010, Effect of planting dates on growth and yield Bt-cotton hybrids (Gossypium hirsutum L.). Crop Improv, 37(2): 204-208.

Sukhbir, Singh, 2010, Effect of planting dates on growth and yield Bt-cotton hybrids (Gossypium hirsutum L.). Crop Improv, 37(2): 204-208.

Surulivelu, T., Sumathi, E., Mathirajan, V. G. and Rajendran, T. P., 2004, Temporal distribution of pink bollworm in Bt cotton hybrids. Int. Symp. On 'Strategies for Sustainable Cotton Production - A Global Vision 2, Crop Production, 23-25 Nov., UAS, Dharwad, 
Karnataka (India), pp. 86-88.

Tayade, A.S., and Dhoble, M.V., 2010, Effect of transgenic Bt-cotton hybrid, nutrient and pest management on seed cotton yield, nutrient uptake and status of available nutrient in the soil. Indian J. Fert., 6(8): 34-40.

Thimmareddy, K., Desai, B. K. and Vinoda Kumar, S. N., 2013b, Uptake of NPK, availability of NPK and quality parameters of Bt cotton (Gossypium hirsutum L.) as influenced by different bio-fertilizers and Insitu Green Manuring under Irrigation. Inter. J. Agric. Envi. Biotech, 6(4): 623-628.

Udikeri, S. S., Patil B.V., Khadi, B. M., Basavanagouda, K. Kulkarni, K. A. and Vamadevaiah, H. M., 2011, Field evaluation of selected first and second generation $B t$ transgenic cotton hybrids in rainfed situation. Karnataka J. Agric. Sci., 24(5): 654-660.

Udikeri, S. S., Patil, S. B., Manjula, M. and Khadi, B. M., 2003b, Estimation of available sprays for bollworm management in $B t$ cotton. In: Proc.World Cotton Conf. 3, 9- 13 March, 2003, Cape Town, South Africa, pp. 1308-1311.

Udikeri, S.S., Patil, S. B., Hedge, R. N., Kulkarni, V. and Patil, S. S., 2003a. Performance of Bt cotton genotypes under unprotected conditions. In Proc. World Cotton Conf. 3.913 March, 203, Cape Town, South Africa, pp. 1282-1286.

Venkateshalu, Kalmat, B., Swamy, L., Sushila, N., Mallapur, C. P. and Reddy, N., 2010, Performance of different Bt cotton hubrids against mired bugs, Reontiadesbise ratense (Distant) (Miridae: Hemiptera), Karnataka J. Agric. Sci., 23(1): 109-110.

Vennila, S., Biradar, V.K., Gadpayle, J.G., Panchbhai, P.R., Ramteke, M.S., Deole, S.A. and Karanjakar, P.P., 2004, Field evaluation of $B t$-transgenic cotton hybrids against sucking pests and bollworms. Indian $\mathrm{J}$. Pl.
Prot., 32 (1): 1-10.

Venugopal, K., Ramasami, M. and Thigarajan, C. P., 2002, Risk assessment and its management in $\mathrm{Bt}$ cotton in India. In: National. Seminar on Bt Cotton Scenario with Special Reference to India, $23^{\text {rd }}$ May, 2002, UAS, Dharwad, Karnataka (India), pp. 70-84.

Venugopalan, M. V., Rachana Deshmukh, Hebbar, K. B. and Tandulkar, N. R., 2012, Productivity and nitrogen-use efficiency yardsticks in conventional and $B t$ cotton hybrids on rainfed vertisols. Indian J. Agric. Sci., 82(7): 641-644.

Waraich, E.A., Ahmed, R., Raja, Hur, G.M., Ehsanullah Ahmad and Mahmood, N., 2011, Response of foliar application of $\mathrm{KNO}_{3}$ on yield, yield components and lint quality of cotton (Gossypium hirsutum L.). African J. Agric. Res., 6: 5457-5463.

Witt, C., Doberman, A., Abdilrachman, S., Gines, H. C., Ghanhuo, W., Nagarajan, R., Satawathanat, S., Tran Thuc Son, Pham Syton, Levantiem, Simbahan, G. and Olk, D. C., 1999, Internal nutrient efficiencies in irrigated low land rice of tropical and subTropical Asia, Field Crops Res., 63: 115138.

Wu, K.M., Geo, Y.Y. and Wang, W.G., 2000, Field resistance evaluations of $B t$ transgenic cotton GK series to cotton bollworm. Acta Phyto. Sinica, 27: 317-321.

Yenagi, B. S., 2006, Studies on performance of Bt cotton genotypes and evaluation of refuge crops/cropping systems, $P h$. D. Thesis. Univ. Agric. Sci., Dharwad, Karnataka (India).

Zaheer, A. D., Shamshuddin, T., Qammaruddin and Chand, F. O., 2014, Impact of planting dates and picking stages on yield and seed maturity of cotton (Gossypium hirsutum L.) varieties. Sarhad J. Agri., 30(4): 404-410.

\section{How to cite this article:}

Vinayak Hosamani, B.M. Chittapur and Venkatesh D. Hosamani. 2017. Key Agronomic Issues for Higher Production and Sustainability in Bt Cotton: A Review. Int.J.Curr.Microbiol.App.Sci. 6(8): 3488-3506. doi: https://doi.org/10.20546/ijcmas.2017.608.418 